\title{
Conceptual Reflections on Ethics for International Research Collaborations in Disaster Impacted Areas from the Experiences in Indonesia, New Zealand and Japan
}

\author{
Christopher Gomez \\ Department of Geography, University of Canterbury \\ Private Bag 4800, Christchurch, New Zaeland \\ e-mail: christopher.gomez@ canterbury.ac.nz
}

\begin{abstract}
The present contribution is by no means a first attempt at considering the ethics in human activities, interactions in disaster impacted areas, but it is more the case of looking at 'international research' that present a very particular difficulty for ethics: the notion of trans-boundary, multi-dimensional idea of one group not really belonging within another, but which will perform functions inside this second group and eventually alter, modify some of the original organs. This paper explain the reflections of the ethical consideration of international research collaboration in disaster impacted areas which are emerged from the experiences in Indonesia, New Zealand and Japan.
\end{abstract}

Keywords: disaster, international research collaboration, ethics

\begin{abstract}
Abstrak
Kontribusi pada artikel ini bukan merupakan ide pertama untuk mempertimbangkan etika dalam interaksi kegiatan di daerah terdampak bencana, tetapi lebih fokus menyoroti tentang kasus 'penelitian internasional' yang menyajikan kesulitan yang sangat khusus terkait etika. Kasus tersebut antara lain terkait gagasan trans -boundary, ide multi-dimensi dari satu kelompok tidak serta merta menjadi hak milik yang lain. Perubahan dan modifikasi dapat mungkin dilakukan oleh kelompok yang lain dari bagian yang asli. Makalah ini menjelaskan refleksi dari pertimbangan etis dari kerjasama penelitian internasional di daerah bencana dampak yang muncul dari pengalaman di Indonesia, Selandia Baru dan Jepang.
\end{abstract}

Kata kunci: bencana, kolaborasi penelitian internasional, etika

\section{Introduction}

Moral value must begin with human valuers, or valuerswhose valuing has ethical meaning. These moral agents are persons who make decisions based on, among other things, notions of right and wrong, good and bad. For a thing to have meaningful moral value, some moral agent must value it as a member of the ethical universe, and it must be the kind of thing to which moral concepts and considerations can refer. C.J. Cuomo. 1998:48

But are there universal moral or ethical values, and can they be applied everywhere by and to everybody, or in other terms should the ethics be the one of a group or the one of an individual or a mix of both, and how dynamic and interoperating these elements of ethics are? Such questions are the one that international researchers in disaster impacted areas face. In the aftermaths of the 2004 Boxing Day tsunami that impacted the coasts of the Indian Ocean, an international scientific team mostly lead by the American, the French and the Japanese went to collect perishable data, in order to improve the scientific understanding of tsunamis. Although one can argue that they contribute to the greater good of their own community, and even the humanity, the question of the impacts of those scientists on locals who are trying to survive, rebuild their communities and be eventually resilient can be perceived as a burden. Therefore, is their coming ethical? Is it morally right? And who can decide what is right, the impacted and suffering locals or the stakeholders that will benefits from it, even sometimes in the name of the locals. The present contribution aims to look beyond these "straw-man based strategies" that are waved as ethical puppets, by providing a short and still incomplete attempt to answering (1) what ethical elements should international disaster research and collaboration consider and why.

Before entering the main argument of this contribution, we should first provide a working definition of ethics. "Ethics is the study of codes of conduct and moral judgments concerning what is right and wrong" (Jenson, 1997, in Geale 2012:445), thus an ethical 
behaviour should conform to these norms, which are set by individuals groups and nations. Dealing with ethics could then be a relatively easiertask if the concept hadn't evolved so much historically to become one of the pivotal concept of debate in the 20th century philosophy (e.g. the famous J.-P. Sartre or J. Rawls...etc.). It is however not the object of the present contribution to enter the different existing debates and the authors will just acknowledge a portion of contemporary ethics that is mostly articulated from the pivot of Kantian deontology, with some of the major streams pertinent to disaster ethics:utilitarianism/consequentialism stream; the deontological stream and the communitarianism stream (LaFolette, 2007).

Within such a rich background, the present contribution is by no means a first attempt at considering the ethics in human activities, interactions in disaster impacted areas, but it is more the case of looking at 'international research' that present a very particular difficulty for ethics: the notion of trans-boundary, multi-dimensional idea of one group not really belonging within another, but which will perform functions inside this second group and eventually alter, modify some of the original organs.

\section{The ethics of disaster impacted areas: international challenges}

\section{To belong or not to belong}

Traditionally, the ethics in disaster-impacted areas have been strongly shaped by army and war-time experiences, when a compact group - an army - tends towards a common goal. Within this background, the traditional ethical approach of disaster-impacted area is most often solved using utilitarianism, which is interested with the outcome of one's action; only the result of the action in term of greater good for the greatest number. This approach has been seen in the aftermath of the February Earthquake in Christchurch at the Christchurch Hospital. The latter was divided into wards with a space for those who could not be saved - or would require too much care for an uncertain result -, those who were lightly injured and could wait and those who were severely wounded but could be saved. This meant that all the injured were not provided with the same level of care, and de facto saving the greatest number was also to the detriment of a minority. Although such behavior is relevant to utilitarian ethics and considered ethical under utilitarian terms, it presents a major difficulty for international research parties. Indeed, the issues of trans-cultural and trans-community collaborations in disaster areas escape this 'conceptional' framework, because intrinsically one part of the collaborating team isn't part of the 'army' as it did not fight the battle, did not suffer the losses, nor did it share the same 'urgency-driven' objectives. There is a part of the team, which does not play under the same rules, there is a part of the team that does not even play the same game.

From this 'traditional perspective', how do we bring reconciliation between the 'locals' and the 'international group' and how can we modify accordingly the conceptual framework. One of the possibility may come from the beneficiary perspective of one action over another in deciding whether the later is ethical or not, and this lesson once again is largely derived from some form of military action.

\section{Moderating the ethics based on 'who' the recipients of one's action are}

Besides the trans-cultural and trans-national issue, the utilitarian ethical position used in disaster impacted areas doesn't make the unanimity, especially when it comes to 'research', because the disaster doesn't create a sense of urgency for the research action - it wouldn't have changed the face of the world if the author did not go and study in Banda Aceh after the 2004 tsunami for instance -, and even if one could argue that the great majority will benefit from the research conducted - and this is in line with the goals of utilitarian ethical theories -, the immediate impacted local individuals and group may not benefit from the research. If in the aftermath of the 2004 earthquake and tsunami in Banda Aceh, the international research conducted in the field greatly helped the understanding of tsunami behaviors, hazards and risks, and even if the results were published in international widely available scientific and popular papers, the chances that any of this work directly or indirectly benefited the local populations is very slim. This issue has been raised following a strong movement that started in the aftermath of the second world-war.

Following the atrocities committed during the Second World War, the Declaration of Helsinki (1964) very clearly stated that non-therapeutic research could not be conducted without the informed consent of the individual, irrespective of the benefits to wider society. (Smyth and Williamson, 2004:6). Although, research ethics has evolved from the Declaration of Helsinki, it remains one of the most important turning point for scientific-research ethics, especially because it creates a relationship between the 'researched' and the researchers, which can then transcend the issues 
of trans-nationality, -culture, community, which have arose with the utilitarianist approach, commonly used in disaster impacted areas.

It also recognizes that regardless of the good that could be generated by the research and the researchers, the researched individuals and what they consider to be ethically acceptable, good for them prevails. This distinction is essential and it is linked to a transition in Europe from the Antic Rome and Greece to a Christian form of ethics as developed by Kant. Kantian ethic, concerned with the right or wrong, the morally just or unjust of one's action is a distinction that western civilization often take for granted, but that can face different set of ethical values in international setting.

\section{Ethics for individuals and in social context}

Take any action allowed to be vicious: willful murder, for instance. Examine it in all lights, and see if you can find that matter of fact, or real existence, which you call 'vice'. In whichever way you take it, you find only certain passions, motives, volitions and thoughts. There is no other matter of fact in the case. The vice entirely escapes you, as long as you consider the object. You never can find it, till you turn your reflection into your own breast, and find a sentiment of disapprobation, which arises in you, towards this action. Here is a matter of fact; but it is the object of feeling, not of reason. (D. Hume. 1978(pub.). Treatise of Human Nature, III; Enquiry concerning the Principles of Morals. Clarendon Press. i.1.)

If the moral behavior is solely subjective, like aesthetics would be, why are different societal groups having similar ethical value systems. In most societies it is negative to kill a member of one's own society, group. Such behavior can also expand to external groups, like when a war enemy forgives one other. Moral behavior can however only emerge from a mutual recognition. In Sparta Greece, if killing another Spartan was disapproved, the killing of slaves by young males was part of a ritual to enter manhood and wasn't perceived as immoral. Similar limits of morality have emerged during the African-slaves trade in America, or the Apartheid in South Africa.

Another field of ethics that looks into these limits, come from the field of environmental feminist ethics. Ethics theorists such as Singer, Regan, Donald VanDeVeer(1995) argues that the benefits of culture ought to be extended to various nonhuman animals, because those animals have the same relevant qualities (such as psychological abilities for instance) that the ones seen in humans. Such rejection of speciesism - theory that place human being above any other form of life (Drewermann, the deadly progress - 1990s) does lead back to the question of integrating the difference, the different into a set of rules and values that give them access to the same ethical consideration.

Considering the construction of a party of international researchers, which reach a disaster impacted area, it is therefore essential that they consider their counterparts as equals, in order to realize the human natural tendency to sympathize - this ability to share in imagination the feelings of enjoying pleasure and avoiding pain, from which Hume's definition of moral behavior is based on. It is therefore, in a first instance, not only the party as a socially organized group, that needs to be moral, ethics, but first and foremost the individuals that compose this group, individuals that need to 'sign' a social contract with the 'disaster impacted group' the researchers are going to work in and with. Indeed Ethics is as much about our character as our actions. Living feminist environmental ethics entails (for some of us) a radical shift in how one sees and interacts with the world. It also requires attention to who we are in the world. In this sense any ethic contains a latent ideal - not just of the best actions and decisions, but of good persons. (C.J.Cuomo, 1998:81). It raises at least two questions (1) how does this individual ethics fit within a social group that tends towards defined goals, and (2) what are the tools and mechanisms of integrating the international researcher as part of the researched social group?

Both Utilitarianism and Kantian ethics - introduced above - and the latter debate dominated by Hume's philosophy are dealing with individuals. But there are other dimensions beyond the individual to the present issue, with for instance, the deontological and communitarianism streams, which look at societies with the idea that a 'social contract' governing the rules of interactions between each individuals, and between the individuals and the group should develop in 'human rights' and systems of fairness in the interactions, as championed in the 20th century by $\mathrm{J}$. Rawls (1971).

Hence, the second part of the machine needing to be ethical is the engine itself, the group, the organization, and not only the individual cogs of the machinery. This meets several challenges in the field of international disaster research, notably because of the funding, political and media mechanisms that drive 
the machine.

These tensors have been largely described in the field of disaster relief: The massive media interest had huge fund raising implications. While initially there was limited commitment from some official donors, the general public in affected developing and developed countries donated generously. Gradually, a competition developed as to which country could do the most and give the most money to the victims. The tsunami response will probably turn out to be one of the best-funded humanitarian operations ever, which seems difficult to reconcile in light of the emergencies that remain "forgotten". In a global era, it is necessary to develop a global humanitarian ethic based on the principles of humanity, impartiality, neutrality and independence. Only by offering humanitarian assistance based on need - and need only - will the humanitarian community be able to fulfil the expectations of those in need. This must remain a more important agenda item than letting the media set priorities for disaster managers throughout the world. (Erik Kjaergaard, 2005:5).

There is also a problem with newly emerging centers of aid conflicting with each other. The world now counts as major aid providers the US, the UN, the European Union/European Commission, Japan, Canada, the UK, the Scandinavian countries and now, with the tsunami, India and China. This is in addition to private benefactors of NGOs and Red Cross agencies. All have distinct policies and varying priorities. While this may ultimately benefit victims of the recent tsunami and other major disasters, the growth has not been in per capita receipt of aid by the victims, but in which NGOs and Red Cross agencies receive the most money for their own purposes. The American Red Cross reports over HK $\$ 2.5$ billion already in hand for the tsunami; but its annual budget for 2003/2004 included fund raising expenses of HK $\$ 1$ billion and administrative costs of HK\$1.4 billion, so it is not clear how much of these new funds will actually benefit victims. (Walden. 2005:7).

The necessity of creating a toolset for a group leading researches in a disaster impacted zone emphasizes the existence of a power-relationship, otherwise this very question would not arise. Therefore a toolset for an equalitarian relation between the two groups may be looked in feminist theory; and Cuomo(1998) gives the following set of rules as constructive elements:

- One different and less powerful will be oppressed and mistreated;

- This oppression and mistreatment [...] is wrong;

- The analysis and reduction of the oppression and mistreatment are necessary (but not sufficient) for the creation and maintenance of the kind of individual and communal lives that should be promoted within good societies;

- Because different forms of oppression are intermeshed, the analysis and reduction of any form of oppression, mistreatment, or unjustified domination is necessary for the creation and maintenance of the kind of individual and communal lives that should be promoted within good societies.

\section{Conclusion}

“In 'The Subjectivity of Values', J.L. Mackie argued that though moral views are subjective conventions held by people, and things can have no objective value, there can still be good reasons for holding them." C.J. Cuomo. 1998. Feminism and ecological communities, an ethic of flourishing (p.46). Because the limits of ethical values both in term of included and excluded concepts and in term of included groups or excluded groups are a set of 'subjective conventions', there cannot be any satisfactory ethics rules between one group moving to a disaster impacted area and the locals of the area if it is not built by both. Therefore, there cannot be one set of document ready for any situation, but rather guidelines to draw bilaterally accepted ethics forms. These agreement needs also to be freed from geopolitical games at play, and that poise several of the hierarchical preconceptions grinding the field of disaster risk.

\section{References}

Card, C. 1995. Lesbian Choices, New York.Columbia University Press.

Cuomo, C.J. 1998. Feminism and Ecological Communities, an ethic of flourishing. Routlege.

Drewermann,E. 1981. Der tödlicheFortschritt: Von der Zerstörung der Erde und des Menschen imErbe des 
Christentums. Regensburg Pustet.

Hume, D. 1978. Treatise of Human Nature, III; Enquiry concerning the Principles of Morals. Clarendon Press. Kjaergaard,E. 2005. Asian Disaster News - January - March 2005, 5.

LaFollette, H. (Ed.). 2007. Ethics in Practice, Blackwell, Oxford.

Rawls, J. 1971. A Theory of Justice Harvard University Press, Boston.

Smyth,M, E. Williamson, 2004. Researchers and their 'subjects - Ethics, power, knowledge and consent.The Policy Press.

Walden, R.M. 2005. Managing Chaos: the disaster after the disaster. in Asian Disaster News January - March 2005, 7-9.

Kjaergaard, E. 2005. Asian Disaster News - January - March 2005, 5. 